\title{
Biodegradation of Agricultural Plastic Films: A Critical Review
}

\author{
Ioanna Kyrikou · Demetres Briassoulis
}

Erratum to: J Polym Environ (2007) 15:125-150 DOI 10.1007/s10924-007-0053-8

Ioanna Kyrikou and Demetres Briassoulis, the authors of "Biodegradation of Agricultural Plastic Films: A Critical
Review," wish to acknowledge that their project was co-funded by the European Union - European Social Fund \& National Resources - O.P. "Education" II.

The online version of the original article can be found under doi:10.1007/s10924-007-0053-8.

I. Kyrikou · D. Briassoulis $(\bowtie)$

Department of Agricultural Engineering, Agricultural University

of Athens, Iera Odos 75, 11855 Athens, Greece

e-mail: briassou@aua.gr 